\title{
Exploring Pragmatic Transfers in Ayoade Okedokun's Mopelola: The Tale of a Beauty Goddess: A Sociolinguistic Perspective
}

\author{
Servais Dieu-Donné Yédia Dadjo (Corresponding author) \\ Dept. of English, Abomey-Calavi University \\ 03 PO Box 3621 Cotonou, Republic of Benin \\ E-mail: dadservais@gmail.com
}

$\begin{array}{lrr}\text { Received: Nov. 10, } 2021 & \text { Accepted: Dec. 20, } 2021 \quad \text { Published: Jan. 9, } 2022 \\ \text { doi:10.5296/elr.v8i1.19258 } & \text { URL: https://doi.org/10.5296/elr.v8i1.19258 }\end{array}$

\begin{abstract}
This research work investigates pragmatic transfers in Okedokun's Mopelola: The Tale of a Beauty Goddess. It aims at identifying, analyzing and interpreting pragmatic features through which specific meanings are conveyed in the selected play. In the attempt to reach this goal, the data are randomly collected from the whole play on the basis of a quantitative method. Then, the statistical results are qualitatively discussed and interpreted in terms of their frequency distribution. The findings show a predominance of pragmatic transfer of loan words representing $33.33 \%$ followed by proverbs $32.14 \%$ and loan-blends $16.16 \%$. Transfers of greetings, insults and apology are low as they represent respectively $3.57 \%, 3.57 \%$, and $2.38 \%$ whereas other transfers such as request, gratitude, offer, blaming/reproaching and advice are almost nonexistent. The high proportions of loan words as well as proverbs suggest the author's determination to value Yoruba culture and tradition. The almost important proportion of loan-blends constitutes a strategy for the author to attract readers' attention on the various authentic Yoruba expressions. The presence of transfer in greetings stresses the peculiarity of Yoruba culture characterized by the expression of profound respect to elderly people. On the other hand, the presence of insults indicates that though Yoruba culture is characterized by the expression of profound respect, some Yoruba people, as the black sheep, do develop arrogance in contradiction to their culture.
\end{abstract}

Keywords: pragmatic transfer, loan words, loan-blends, speech acts 


\section{Introduction}

Language is a vital tool of communication in human societies. As nobody can live in a human society without the need of expressing their ideas, feelings, needs, Traugott and Pratt (1980) describe the importance of language as follows: 'Language is around us everywhere, in speech, writing, sign language, or simply in our mind as we dream, remember conversation, or quietly think out a problem. It is a vehicle of power, a means by which we control, create and preserve' (Traugott \& Pratt, 1980, p. 1). This excellently recapitulates the fundamental importance of language.

Thus, it can be contended that language characterizes our daily life and a successful interaction results from mutual understanding. Consequently, a clear-cut understanding of a speech event requires a thorough consideration of the context in which it takes root. This leads Hasan (1985) to advocate that: 'Languages need communities to live in; they develop and change through their use in the living of life, and this characteristically takes place in social contexts of culture' (Hasan, 1985, p. 10). This clearly shows that language is social context-dependent. It is highly important to have a good understanding of language context so as to decode suitable meanings and pragmatics is the linguistic field that helps decode speakers' intended meanings.

In this respect, this research work investigates pragmatic transfers in Okedokun's Mopelola: The Tale of a Beauty Goddess. It aims at identifying, analyzing and interpreting pragmatic features related to different types of transfers used to convey specific meanings through the play. The compelling reason that motivates the selection of this play lays on the author's idiolect characterized by a massive presence of Yoruba expressions in his literary work. Such a massive presence requires scrutiny so as to explore the various pragmatic transfers used by the author to convey specific meanings.

\section{Method}

A mixed method is used to carry out this research work: quantitative and qualitative methods. The study attempts to explore pragmatic transfers in a selected literary work which is a play through which the Nigerian writer Ayoade Okedokun basically depicts Yoruba culture and tradition. Basing on the quantitative method, the pragmatic transfers of loan words, proverbs, loan-blends, greetings, insults, apology, request, gratitude, offer, blaming/reproaching as well as advice have been identified in the whole play and their frequency distribution has been determined. Illustrative instances of specific transfers have been highlighted in bold and their corresponding contextual explanations have been provided in italics. A figure has been designed to recapitulate the proportions of the different pragmatic transfers identified in the play. This has enabled the researcher to make insightful discussion and interpretation of the findings following the principles of the qualitative method.

\section{Literature Review and Theoretical Framework}

\subsection{Language, Context and Culture}

Language is obviously a vital tool that helps convey meaningful messages through everyday conversations, speeches, preaches, literary works to mention just a very few instances. It is 
the most important part of our being as it determines our cultural identity. Language is closely related to culture. It is in this sense that Hasan (1985) contends that 'the relationship between language and culture is symbiotic: the one lives through the other' (Hasan, 1985, p. 10). In the same sense, Newmark (1991) argues that 'language is a substantial but partial reflection of a culture. A language reflects the culture of a society, not only in its option of vocabulary, but also in its syntax, and way of organizing ideas. In single context world, the author communicates with the source text readers who share the same cultural background knowledge with him/her' (Newmark, 1991, p. 73).

In the same way, context is an important concept in language study. The relationship between language and its context of production is highly important to decode meaning. This leads Spencer and Gregory (1970) to make the analysis of two concepts which are context of situation and context of culture. The context of situation relates to the situation in which a speech event takes place whereas context of culture also called cultural contextualization derives from the assumption that a text may be regarded as part of a complex social process. For Halliday (1978), the concept of context consists of three strata: context of culture, context of situation and co-text. Context of culture and context of situation are outside of language itself. Co-text, also known as linguistic context, is certainly inside of language itself. As for him there is a close interdependent relationship between language and context. Context determines and is constructed by the choice of language. On the one hand, language, considered as a system (its lexical items and grammatical categories) is related to its context of culture, genre. While on the other hand, the specific text and its component parts are related to its context of situation, register, and co-text is related to the discourse itself.

It can be inferred from the above arguments that a thorough analysis of literary text requires personal, social, linguistic, literary and ideological circumstances in which the text is produced. Igboanusi (1997)'s study on Varieties of Nigerian English: Igbo English in Nigerian literature excellently illustrates this as it shows that Nigerian English's peculiar and very effective linguistic style creates no readership and semantic problems for the Igbo or African reader whereas the European or Western reader, whose language has been used, may have semantic difficulties arising from lack of knowledge of the Igbo culture and world view. He argues that an understanding of the tradition which gives rise to such texts and also a proper placement of contexts in which such usages occur will certainly enhance their interpretation and understanding.

It, obviously, goes without saying that in order to have a deep understanding of a literary text, one must take into account its context of culture and that of situation. Koussouhon (2009) excellently proves this in his article Lexico-Pragmatic Transfer in Anglophone African Fiction: A Comparative Reappraisal. After a thorough description of Anglophone African fiction, he asserts that: 'The overall discourse of African fiction, in general, and of Achebe's and Ngugi's novels, in particular, cannot be fully apprehended by a reader who is not a bit conversant with the broad contexts of Igbo or Kikuyu cultures or worldviews and the immediate contexts of situation' (Koussouhon, 2009).

In line with what has been reviewed thus far, this research work explores pragmatic transfers 
in Okedokun's Mopelola: The Tale of a Beauty Goddess in order to identify, analyse and interpret pragmatic features used to convey specific meanings through the selected play. It is thus important to account for the pragmatic theory that underpins this work.

\subsection{Defining Pragmatics and Pragmatic Transfer}

Leech (1983) simply defines pragmatics as 'how langage is used in communication' (Leech, 1983, p. 1). For Mey (2001), 'pragmatics studies the use of langage in human communication as determined by the conditions of society' (Mey, 2001, p. 6). On his part, Kroeger (2018) contends that pragmatics is concerned with those aspects of meaning that depend on or derive from the way in which the words and sentences are used (Kroeger, 2018, p. 4).

It is important to note that pragmatics encompasses speech act, conversational implicature, politeness etc. As far as pragmatic transfer is concerned, Barron (2003) simply views it as the influence of learners' L1 knowledge and culture on the target language in terms of understanding, production, and acquisition. In the framework of this research work some sociolinguistic key concepts are required for the exploration of pragmatic transfer. Such concepts are briefly explained as follows:

- Words borrowing, also known as loanword: a process through which speakers adopt words from a source language into their native language. In other words, it refers to words used by a speech community that speaks a different language from the one the words originate.

- Loan-blends: a word that is composed of parts of different languages.

- Proverbs: a simple, concrete and traditional saying that expresses a perceived truth based on common sense or experience. Proverbs are often metaphorical and use formulaic language. Collectively, they form a genre of folklore.

- Yorubaism: expressions reflecting a very particular aspect of Yoruba tradition which is literally translated into English in which the sense looks generally unusual. Such expressions are easily understood in Yoruba but are either lacking in English contexts or are used in different ways in English.

- Colloquialism: it is a word or a phrase that is not formal or literary and is used in ordinary or familiar conversation.

- Comparison: is the act of evaluating two or more things by determining similarity or difference of the relevant and comparable characteristics of each thing.

- Idiomatic expressions: they are types of informal language that have a meaning different from the meaning of the words in the expressions.

- Metaphors: it is a figure of speech that describes an object or action in a way that is not literally true, but helps explain an idea or make a comparison. A metaphor states one thing which actually means another thing through a process of symbolism or comparison. 
- Incantation and prayers: a spell, a charm, an enchantment or a bewitchery that have magical effect on a person or objects. The formula can be spoken, sung or chanted. They can also be performed during ceremonial rituals.

\subsection{Types of Pragmatic Transfer}

Pragmatic transfer occurs in oral and written communication. Depending on the context, the transfer of linguistic features is done through speech acts. A speech act is viewed as 'an action performed by means of language, such as requesting something, complaining about something, or refusing something' (Al-Kahtani, 2005, p. 7). Indeed, speech act may function as apology, greeting, request, blaming, offer and refusal.

- Pragmatic Transfer in Apologies: it is a regretful acknowledgement of offense. In some cases, it is an assurance that no offense was intended (Hornby, 1989).

- Pragmatic Transfer in Refusals: it is the right or privilege of deciding to take or leave a thing before it is offered (Hornby, 1989). There are many cases of refusals: refusal to request, refusal to invitation, refusal to offer and refusals to suggestion which occur through different formulas. The formulas may be direct or indirect.

- Pragmatic Transfer in Request: it is an act of asking for something or permission to do something or the fact to ask to be given/allowed/favoured with something.

- Pragmatic Transfer in Gratitude: the fact of being thankful or making an appreciation towards something or an inclination in order to return kindness (Hornby, 1989).

- Pragmatic Transfer in Offer: the fact to hold out in hand and tender for acceptance or refusal. It is also the expression of readiness to give or do something if desired.

- Pragmatic Transfer in Greeting: the fact to salute with words or gestures. Transfer in greeting may be the formula used to greet someone in a foreign language using one's usual ways of greeting which may not be the right formula in the target language.

- Pragmatic Transfer in Blaming/Reproaching: the fact to find fault with somebody. In the same way, reproaching deals with conveying protest or censure.

\section{Results}

The analysis of pragmatic transfer consists in identifying the different sociolinguistic aspects through which pragmatic transfer occurs in the selected play.

\subsection{Loan Words and Loan-Blends}

It is important to note that some Yoruba words have been borrowed to keep their full meaning in the play. Such words are referred to as loan words. There are also some loan-blends which are nominal groups made of a combination of lexical items from both Yoruba and English.

- Loan Words

An important number of loan words has been identified in the selected play. The list below displays some selected loan words highlighted in bold for illustration. 


\section{Macrothink}

(1) 'The Ifa priest is at the centre with his divination chain in his hand.' (p. 7)

(2) 'Kabiyesi, we thank Olodumare, the Supreme Being, the Ultimate Carved the head of man, the All-Knowing that knows the destiny of snail foetus inside the shell, for this beautiful gift of a baby' (p. 7).

(3) 'You are right, holy one, Eji-Ogbe.' (p. 8)

(4) 'Iyalode receives the calabash on behalf of the king and opens it.' (p. 16)

(5) 'It won't take much time, your highness. Ifa Oloja;' (p. 11)

(6) 'Bring the pot and let everybody swear to Ogun' (p. 38)

(7) 'Kere o! Kere o! Kere o!- Here comes the message from the king' (p. 43)

(8) 'Oosa Omi! That is my father'. (p. 47)

(9) 'The royal One, where is the Iyale Ori?' (p.47)

(10) '...but the day he killed Orangbankogbi, he brought it home for his parents'. (p. 60)

(11) 'Muso! Muso! Muso!!!' (p. 66)

(12) 'Ask Orunmila' (p. 108)

(13) 'Otun, do you ask a house-wife how she comes about pregnancy?' (p. 119)

(14) 'I even asked of his name and I was told, Oyibo' (p. 122)

In sentences (1), (2), (3), (4), (5), (6), (7), (8), (9), (10), (11), (12), (13) and (14) above, the highlighted words are borrowed from Yoruba to mean respectively in English:

- Ifa Oracle

- Kabiyesi.... Olodumare Our king.... God

- Eji-Ogbe the king of the corpus.

- Iyalode Chieftaincy

- Ifa Oloja The oracle of the king

- Ogun god of iron and war

- Kere o! Kere o! Kere o! Your attention please!

- Oosa Omi! The goddess of water!

- Iyale Ori King's mother

- Orangbankogbi the father of all troubles

- Muso! Muso! Muso!!! They are jubilating.

- Orunmila' father of oracle 
- Otun

- Oyibo
Right-hand-man

The White

The above instances show that Okedokun has made a massive use of loan words that may create a great readership problem to non-Yoruba conversants. In other words, readers need to have Yoruba background in order to decode meaning from the selected play.

- $\quad$ Loan-Blends

Loan blend is another form of borrowing whereby new meanings are formed by the combination of different languages. Some loan blends used in the selected play are highlighted in bold for illustration:

(15) 'As light focuses on the stage, the Ifa priest, the child's mother' (p. 7)

(16) '...we thank Olodumare, the Supreme Being, the Ultimate Carver that calved the head of man' (p. 7)

(17) 'Chief Balogun, a war general.' (p. 12)

(18) 'Welcome Baba-awo. What is the oracle saying?' (p. 96)

(19) 'Ask Orunmila, the father of Ifa, the owner of the corpus'. (p. 108)

(20) 'From Ile-Ife, the land spread to all where you have the earth today'. (p. 126)

In sentences (1), (2), (3), (4), (5), (6), (7), (8), (9), (10), (11), (12), (13) and (14) above, the highlighted words are borrowed from Yoruba to mean respectively in English:

- Ifa priest

- thank Olodumare

- Chief Balogun

- Welcome Baba-awo

- $\quad$ Ask Orunmila

- $\quad$ From Ile-Ife

\section{Chief priest}

All the thanks to Almighty God.

head of command war

welcomed the chief priest

ask the father of priest

From an old Yoruba city located in the southwest of Nigeria,

\subsection{Transfer of Yoruba Proverbs into English}

As mentioned in the framework above, a proverb is a simple and concrete traditional saying that expresses a perceived truth based on common sense or experience. Proverbs are often metaphorical and use formulaic language. Collectively, they form a genre of folklore. in African societies, oral communication is considered as an art. Thus, in order to convey specific meanings, Africans refer to specific styles like proverbs. The following list presents some Yoruba proverbs highlighted in bold with their contextual meanings in italics:

(1) 'My father used to say, he who saw me during the turbulent time sees me' (p. 15) / The king is grateful to his people for their support during his barrenness period. 
(2) 'He who tarries to take his food will eat with a golden plate' (p. 16) / The king's family deserves all the gift received on Mopelola's birth ceremony since the king has waited for a long time before having a child.

(3) 'Let's call a hoe a hoe; calling it and instrument for gathering weeds is a waste of words' (p. 21) / Mopelola uses it to claim for her title since she knows that she will be a queen.

(4) 'As soon anus is trained to fart in silence, so also some noses are trained to detect secrets' (p. 22) / It is used to mention that Iyale Ori is aware of Mopelola's business plans.

(5) 'The secret of the snake is its belly' (p. 23) / Iyale Ori is retaliating from Mopelola's attitude for keeping things from her.

(6) 'It is nothing serious but as our elders will say, the finger that sizes the nose is the appropriate one to clean it' (p. 26) / Mopelola finds in her guests (Akinboro, Gbagi and Dada) the suitable men to concretize her plan of making a masquerade

(7) 'Our fathers, in their wisdom, said that you don't sail on furious water with fury. ( $\mathrm{p}$.

44) / The king is approving a peaceful way to avoid war between his kingdom and the neighbor kingdom of Olugbodi.

(8) 'Baba, an old man that is running inside the bush, if he's not pursuing something, definitely something is pursuing him' (p. 56) / Mopelola is trying to tell the Chief priest that there is problem to which she needs to consult the oracle in order to find out the solution.

(9) 'It is the saying of our elders that the rat that has made its track never runs astray' (p. 66) / Dingi is encouraging his troops of warriors through their experience on war field.

(10) 'The gentleness of a tiger is not a sign of weakness' (p. 67) / Poro is trying to caution his commander in chief so as not to underestimate their opponent.

(11) 'Had a stomach been a calabash, I would have open mine for you to see how happy I am' (p. 79) / Balogun is expressing sincerely his joy as Mopelola has won the war which he, as a man has never won.

(12) 'A child may have many clothes as the elder but can he have many rags as the elder?' (p. 79) / Mopelola is saying that Balogun's experience will be useful for them to completely win the war.

(13) 'The falcons cannot hear the falconer' (p. 82) / No one from Olugbodi's warriors can respond to the whistle call since all of them are dead.

(14) 'You can't drown a frog by dipping it into water' (p. 93) / The king is urging his mother to leave Mopelola since she refuses to return the rod of power to the priestess.

(15) 'A message cannot be shared by knife, no matter how big or heavy it is, we still have to deliver it by word of mouth' (p. 99) / Otun is instigating the priest to tell them the options they have concerning the one who is going to remain on the throne between the king 
and his daughter.

(16) 'The saying of our elders, he who has a child will die buried by a child and he who has not will equally die buried by a child' (p. 100) / The king is accepting to die on the behalf of her daughter Mopelola since two kings cannot reign in a single kingdom.

(17) 'Women are the salt of life' (p. 104) / Sanda is showing the wine seller the importance of getting many wives.

(18) 'No matter what, the tongue alone cannot chew meat without the participation of the teeth' (p. 108) / As human being, men and women complete each other for the purpose of procreation. Therefore, Mopelola cannot conceive without a man since she wants to conceive without a man in her life.

(19) 'Your Highness, he who seeks what nobody has ever found will see what nobody has ever seen' (p. 109) / The priest is cautioning the queen about the eventual outcome of the ritual of conceiving an extraordinary child without a man.

(20) 'He who wants to harvest the honey inside the rock must not complain about his axe' (p. 109) / The queen Mopelola is assuring the priest that she is ready for any kind of sacrifice.

(21) 'A pigeon never deserts its owner in time of trouble' (p. 123) / The priest is trying to show his faithfulness to the queen by choosing to follow her to wherever she may go.

(22) 'Wherever the snail, its shell shall be. (p. 124) / The priest is insisting on following the queen to wherever she may go since it is his duty

\subsection{Incantations and Prayers}

In Yoruba culture, there are different type of incantations and prayers. Okedokun uses two types of incantation and prayers. The first one is the incantation and prayer in traditional habits illustrated as follows: 'This is how they did it for Olugbon that made his life smooth; they did it for Areas; the palm-oil magnate, his life knew no evil, the same for Orangun; the palm-wine tape, and his life was as sweat as honey. Mopelola Asake! (He touches the child's head with the divination chain) this is your own. Ifa, answer us the way we ask. Orunmila, the short granddad with belly of wisdom, answer us' (p. 8). Here, the oracle priest uses some words to praise the ancestors and bless the new born (Mopelola) by touching her head with the divination chain. This indicates the traditional habits and ways African elders use some words for the purpose of expressing magical effects. The second one is the incantation used by Otun after receiving praise and homage from Akigbe and the town folks to show the way he is happy: 'Thank you once more. We are very proud of you. May the sun that rises today bring more fortune to our land. May we know the time this child joined us for better-may we know it for abundance of life, plenty of money, plenty of children, plenty of wives, and plenty of good things' (p. 13). This is the prayer the Right-hand-man makes for Olugbodi people to express gratitude. This prayer means that God will bless them in multiple and allow them to know the good time of the child. 


\subsection{Yorubaism in Mopelola: The Tale of a Beauty Goddess}

As mentioned in the theoretical framework, yorubaism constitutes expressions reflecting a very particular aspect of Yoruba tradition which are literally translated into English. The meaning of such literal translation looks generally unusual in English. The following examples illustrate this:

(1) 'A child beholds not the oracle just for fun,'

(2) 'An elder beholds not the oracle for free,'

(3) 'Whoever beholds the oracle must be intimidated.'

(4) 'Thus divined for Orunmila,'

(5) 'The day he was on a journey to Ode Ijan,'

(6) 'He was told to sing whenever he beholds the oracle.'

(7) 'We behold the oracle, we behold good things,'

(8) 'We behold the oracle, we behold good thing,'

(9) 'We behold the oracle, we die no more.'

(10) 'We behold the oracle, we behold good things.'

(11) 'Kabiyesi, I behold a king' (p. 9).

In this passage, Baba Awo chants the corpus to praise Mopelola who will become the Queen. It is a particular way in Yoruba tradition to prepare a queen/king to be. A transmission of cultural value aiming to reinforce the future queen's mindset. In the following examples, Chief priest chants the Ika corpus to stress Yoruba traditional totem.

(1) Chief Aro of Ika land must not eat dog,

(2) Chief Odofin must not eat ram,

(3) likewise it is forbidden for the Ejemu of Ika to eat he-goat

(4) and the overall head of the whole clan must not taste dog head.

(5) Adjust your hands for me, I will adjust my legs, so a weaver moves round the pegs (p. 57).

Here, the Chief priest puts emphasis on the different things which each member of the clan should not eat so as to avoid troubles.

\subsection{Pragmatic Transfer in Apology}

Apology is a speech act which requires attention in the selected play. It is used in usual formulas 'I am sorry' as in: 'Baba-Awo, am sorry, we would have to suspend everything for now. My guests are already around' (p. 11). Here the king is apologizing the chief priest to let him go and meet his guests. Another example in this case can be identified in Olori statement: 
'Nope!-Sorry, mother, I didn't know you're around' (p. 22). Olori is apologizing Iyale-Ori for breaking up their conversation.

\subsection{Pragmatic Transfer in Refusals}

Refusal is a common speech act used in low proportion in the selected play. Transfer in refusal is characterized by a specific way to mean 'no' as in: 'Bring those gifts we packed last night. Give my brothers one each. It is good clothing. You will like it. No! - No - no - no - we are supposed to bring something to our Princess' (p. 27). Here Akinboro is refusing the princess' offer. Another example of transfer in refusal is: 'That is foolish counseling. Foolishness I call it, that I, Asake Mopelola Alawo Ikete should become a wife to that imbecile, God forbid' (p. 44). In this passage, Mopelola is arguing that what her father asks her cannot be possible because her grandfather never bows to a threat throughout his reign until he joins his ancestors.

\subsection{Pragmatic Transfer in Request}

Transfer in request is used in low proportion in the selected play. The following instance is selected for illustration: 'Kabiesi, the Olu of Olugbodi is asking us to choose between war and peace but his peace carries a price tag of tributes. If we choose peace, he expects us to pay tributes to him. That is my little knowledge, Kabiesi' (p. 60). This is a special request addressed to the King and the people of Ikimoko village by the King of Olugbodi inviting them to follow his suggestions so as to avoid war. This request is not made up with ordinary formulas but in a special traditional way basing on the use of natural elements such as bullets, gun powder, piece of white cloth and some cowries.

\subsection{Pragmatic Transfer in Gratitude}

In this play, gratitude is expressed through the usual 'thank you' followed by a prayer or proverb to strengthen kindness in a particular way. The following examples illustrate this: 'The royal messenger, thanks for the message. Give my appreciation and sincere gratitude to His Highness. May our ancestors grant us enough life to be able to pay back' (p. 17) In this example, the Ikimoko King thanks the Olu of Iko for the gift he sends for the princess Mopelola Asake. He prays for him to have the reward of what he has done by considering him.

\subsection{Pragmatic Transfer in Offer}

The usual formula from Yoruba culture here is based on explaining the reasons that underpins the offer so as to convince the addressee. The Ikimoko people offer goods to the new born (Mopelola Asake) during her naming ceremony as illustrated in this example: 'Kabiyesi, our people have extended hands of honour in welcoming our princess to our midst. By last country, twelve baskets of costly beads, two thousand pieces of expensive clothes, two hundred heads of goats, ten heads of thorough bred horses, slaves and lands have been donated to our princess' (pp. 14, 15). This passage shows Ikimoko people's kindness, happiness and attachment to their King. 


\subsection{Pragmatic Transfer in Greetings}

It important to note that in Yoruba culture, there are several ways of greetings. Here, the author has transferred directly the uncommon ways of greetings in Yoruba into English. The following examples illustrate some Yoruba ways of greetings highlighted in bold with their contextual meaning in italics:
(1) 'Ago Onile o' (p. 107)
/ Hello is anybody in?
(2) 'Ago Ya' (p. 107)
/ Yes, who is it?
(3) 'Ka-bi-ye-si-o!' (p. 14)
/ Your highness.

It appears that Okedokun refers to Yoruba ways of greeting that are typical to the native speakers.

\subsection{Pragmatics Transfer in Blaming/Reproaching}

Transfer in blaming and reproaching is made in a particular way as illustrated in this example: 'Do you blame them? I don't blame them at all. Rather, we should blame the lame among us who is calling for war. What do you expect? Our fathers said the day a child killed a bird, he ate it alone, he killed mice, ate them alone, he caught a fish and ate it alone, but the day he killed Orangbankogbi, the father of all troubles, he brought it home for his parents' (p. 60). In this example, the Right-hand-man is blaming Mopelola as she insults the Prince of Olugbodi, by the way she stones their messengers and the way she organizes a raid against the Olugbodi and then the consequences of her behavior.

\subsection{Pragmatics Transfer in in Advice}

Another type of transfer used in Mopelola: The Tale of a Beauty Goddess is transfer in giving advice illustrated as follows: 'Young men, think first about your safety. Mope's soldiers are all over the places. So, be careful how you move' (p. 84). This passage shows how Apaara advises soldiers to rescue their life because what they have seen is different from what they are expecting before the war.

\subsection{Pragmatic Transfer in Insults}

There is also transfer in insults illustrated as follows:

(1) 'Do you have to greet every dog that passes through your land even without permission? Honor should be given only to those who deserve it' (p. 33)

(2) 'Would I have chosen an imbecile out of all the lame crabs around?' (p. 35)

(3) 'Go ahead and say what you heard, lazy man. How many of your mates are at home by now?' (p. 116)

In example (1), the author transfers insult in the way Yoruba people use it with the expression 'every dog' which is a way of humiliating someone. In example (2), the insult is used to make the listener realize what he does not need to say or to do. Such kind of insult is generally ended with a short question. In example (3) the insult starts with an imperative 


\section{Macrothink}

statement like 'Go ahead...' and ends with the expression 'lazy man' Iya Sola uses this typical insult to threaten Ojo.

\section{Discussion and Interpretation of the Findings}

The analysis shows that pragmatic transfer is a highly relevant linguistic work particularly in Anglophone literature produced by African writers. The figure below recapitulates the frequency distribution of the different pragmatic transfers identified in the selected play:

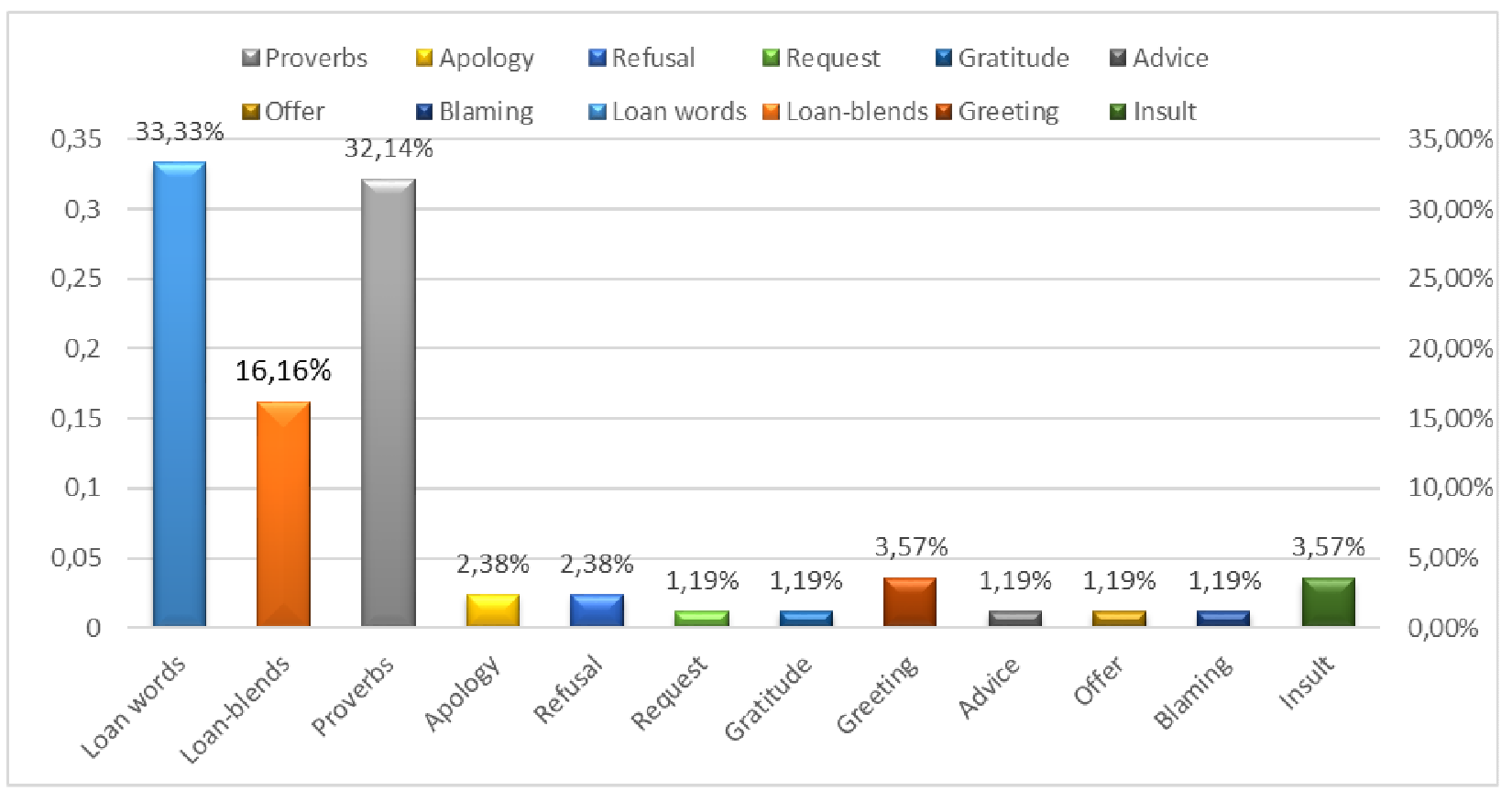

Figure 1. Frequency Distribution of Different Pragmatic Transfers

Source: Dadjo, 2021.

It appears in the figure above that, there is a high proportion of loan words as they represent $33.33 \%$ of the different pragmatic transfers identified in the selected play. This regular reference of the native language indicates the author's attachment to Nigerian culture which he excellently values through the play. Pragmatic transfers of proverbs represent $32.14 \%$. they are used to highlight cultural riches of Yoruba. Loan-blends have been used in the play with about $16.16 \%$. The combination of Yoruba expressions with English words is purposefully done by the author to claim an important place for Yoruba language beside English which is a worldwide language. Pragmatic transfers in greetings represent $3.57 \%$, insults $3.57 \%$, apology $2.38 \%$ whereas other transfers such as request, gratitude, offer, blaming/reproaching and advice are almost nonexistent.

From the above findings, the high proportions of loan words (33.33\%) as well as proverbs (32.14\%) suggest the author's determination not only to convey meaningful and understandable messages to Yoruba and non-Yoruba speakers but also to value Yoruba culture. 
This determination to value Yoruba culture confirms to Sapir's (1921) view about the importance of language as he contends that: language is not only a vehicle for the expression of thoughts, perceptions, sentiments, and values characteristic of a community; it also represents a fundamental expression of social identity.' It can thus be contended that language is not only a means of communicating thoughts and ideas, but also a means of forging friendships, socio-cultural ties, socio-cultural identities, political, economic and religious relationships.

The almost important proportion of loan-blends $(16.16 \%)$ constitutes a strategy for the author to attract readers' attention on the various authentic Yoruba expressions as far as its particular way to convey messages is concerned. This style constitutes the author's idiolect characterized by a high use of loan words, proverbs as well as loan-blends. The presence of greetings $(3.57 \%)$ stresses the peculiarity of Yoruba culture characterized by the expression of profound respect to elderly people. On the other hand, the presence of insults $(3.57 \%)$ indicates that though Yoruba culture is characterized by the expression of profound respect, some Yoruba people do develop arrogance in contradiction to their culture. Such people can be considered as the black sheep of Yoruba people. The presence of apology $(2.38 \%)$ and refusal $(2.38 \%)$ stresses the peculiarity of Yoruba culture to express not only sorrow but also refusal in a very polite way to elderly people. Request, gratitude, offer, blaming/reproaching and advice are almost non-existent are they represent each $1.19 \%$.

It can thus be inferred from the above discussion that Okedokun has africanised English to value African culture and tradition and more specifically Nigerian culture and tradition. The high pragmatic transfers of loan words, proverbs as well as loan-blends requires the consideration of the context in which the play takes root and creates a readership problem for readers who have not any Yoruba background at all. It can thus be contended that this confirms (Koussouhon, 2009)'s view about Anglophone African fiction as he advocates that: 'The language of an Anglophone African fiction, though largely written in the English language, heavily draws on African lexis and cultural, philosophical, religious, and even ideological concepts to convey the 'Africanness' or African context that it has depicted' (Koussouhon, 2009).

\section{Conclusion}

This research work has attempted to explore pragmatic transfers in Okedokun's Mopelola: The Tale of a Beauty Goddess. It aims at identifying, analyzing and interpreting pragmatic features related to different types of transfer used to convey specific meanings through the play. On the basis of a qualitative method, the different pragmatic transfers have been identified and their frequency distribution has been determined. The results then show a predominance of loan words representing $33.33 \%$ followed by proverbs $32.14 \%$, loan-blends $16.16 \%$, greetings $3.57 \%$, insults $3.57 \%$, apology $2.38 \%$ whereas other transfers such as request, gratitude, offer, blaming/reproaching and advice are almost nonexistent.

The high proportions $(33.33 \%)$ of loan words as well as proverbs $(32.14 \%)$ suggest the author's determination not only to convey meaningful and understandable messages to Yoruba and non-Yoruba speakers but also to value Yoruba culture and tradition. Thus, it has 
been noted that language is not only a means of communicating thoughts and ideas, but also a means of forging friendships, socio-cultural ties, socio-cultural identities, political, economic and religious relationships. The almost important proportion of loan-blends $(16.16 \%)$ constitutes a strategy for the author to attract readers' attention on the variety of Yoruba authentic expressions as far as its particular way to convey messages is concerned.

\section{Acknowledgments}

I hereby express my gratitude to Professors Léonard Koussouhon, Innocent Koutchadé and Celestin Amoussou for their relevant advice.

\section{References}

Al-Kahtani, S. A. W. (2005). Refusals Realizations in Three Different Cultures: A Speech Act Theoretically-based Cross-cultural Study. Journal of King Saud University.

Barron, A. (2003). Acquisition in Interlanguage Pragmatics: Learning how Do Things with Words in a Study Abroad Context. Amsterdam: John Benjamins Publishing. https://doi.org/10.1075/pbns.108

Halliday, M. A. K. (1978). Language as Social Semiotic: The Social Interpretation of Language and Meaning. London: Edward Arnold.

Hasan, R. (1985). Linguistics, Language and Verbal Art. Oxford: Oxford University Press.

Hornby, S. A. (1989). Oxford Advanced Learner's Dictionary. Oxford: Oxford. University Press.

Igboanusi, H. (1997). Varieties of Nigerian English: Igbo English in Nigerian Literature. Multilingua, Journal of Cross-Cultural and Interlanguage Communication, 20(4).

Koussouhon, A. L. (2009b). Lexico-pragmatic transfer in Anglophone African fiction: A comparative reappraisal. Particip' Action, 1(2).

Kroeger, P. R. (2018). Analyzing meaning an introduction to semantics and pragmatics. Berlin: Language Science Press.

Leech G. N. (1983). Principles of Pragmatics. London and New York: Longman.

Mey, J. (2009). Concise Encyclopaedia of Pragmatics (2nd ed.). Oxford: Elsevier.

Newmark, P. (1991). About Translation. Multilingual Matters Ltd.

Okedokun, A. A. (2008). Mopelola: The Tale of a Beauty Goddess. Lagos: Febel books.

Sapir, E. (1921). Language: An introduction to the Study of Speech. Harcourt, Brace \& World, New York.

Spencer, J. M. J. G. (1970). An approach to the study of style. In D. Freeman (Ed.), Linguistics and Literary Style. New York: Holt, Rinehart and Winston.

Traugott, E. C., \& Pratt, M. L. (1980). Linguistics for Students of Literature. London and 


\section{Macrothink

New York: Harcourt Brace Jovanovich, Publishers.

\section{Copyright Disclaimer}

Copyright reserved by the author(s).

This article is an open-access article distributed under the terms and conditions of the Creative Commons Attribution license (http://creativecommons.org/licenses/by/4.0/). 